\title{
Editorial Introduction: Architectural Projections of a 'New Order' in Fascist and Para-Fascist Interwar Dictatorships
}

\author{
Roger Griffin \\ Oxford Brookes University \\ rdgriffin@brookes.ac.uk \\ Rita Almeida de Carvalho \\ Instituto de Ciências Sociais da Universidade de Lisboa \\ rita.carvalho@ics.ulisboa.pt
}

\begin{abstract}
The three articles that follow are the second part of a special issue of Fascism devoted to case studies in 'Latin' architecture in the fascist era, the first part of which was published in volume 7 (2018), no. 1. The architecture of three clearly para-fascist regimes comes under the spotlight: those of Spain, Portugal, and Brazil, in each of which a genuine fascist movement was either absorbed into a right-wing dictatorship (as occurred under Franco) or disbanded by it while perceptibly retaining some fascist elements (as in the case of the Salazar and Vargas regimes). Once again, the juxtaposition of the articles reveals unexpected elements of internationalism, entanglements, and histoires croisées both sides of the Atlantic in the impact of the fascist experiments in Germany and Italy.
\end{abstract}

\section{Keywords}

fascism - para-fascism - Portugal - Brazil - Spain - architecture - dictatorships interwar period

The three articles that follow are the second part of a special issue of Fascism devoted to case studies in 'Latin' architecture in the fascist era, the first part of

(c) GRIFFIN AND ALMEIDA DE CARVALHO, 2018 DOI 10.1163/22116257-00702001

This is an open access article distributed under the terms of the prevailing CC-BY-NC license at the time of publication. 
which was published in volume 7 (2018), no. 1. ${ }^{1}$ The project originated in the initiative of Rita Almeida de Carvalho, postdoctoral research fellow in cultural history under Salazar at the Institute of Social Sciences of the University of Lisbon (ICS) to visit Roger Griffin (History, Oxford Brookes University) in May 2013 after reading his Modernism and Fascism. Though that volume was concerned predominantly with making an elaborate case for seeing the totalitarian experiments of Fascism and Nazism within the wider context of socio-political and aesthetic 'modernism', as a specialist in the interwar period of her own country, Rita immediately grasped its potential relevance to a radical reappraisal of the nature of cultural production under Salazar's dictatorship. His regime was assumed by many scholars in Portugal and beyond (often working with Marxist premises) to be fascist, and by the same token reactionary, and hence hostile to the ethos of modernity and any sort of 'progressiveness'. Almeida de Carvalho, on the other hand, saw Salazarism as too rooted in traditional social and Catholic visions of society to be fascist, and yet at the same to be attempting in its own way to institute an alternative modernity, and secure the institutional bases for a stable, productive and uniquely Portuguese future.

Her own work had independently confirmed that, even if Salazar's Portugal was not fully fascist, some of its most forward-looking artistic elites and social theorists aspired to take advantage of the suppression of liberal democracy (which was widely seen as locked in a phase of terminal decline as the basis for civilization) and the increasingly authoritarian state to pioneer a dynamic synthesis of conservatism and modernity so as to realize its own ideal of a healthy society. This would replace the stagnation, backwardness and anarchy of a fledgling democratic Portugal with a corporatist, Catholic, but rejuvenated and modern state, capable of defending the nation from the twin threat posed both by communism and the most 'pagan', radical, and socially disruptive forms of fascism. From this perspective, it was not just cynical propaganda that led the regime which emerged from the new constitution of 1933 to be baptized Estado Novo, the New State. It was chosen also, at least for Salazar and some within his political, intellectual and creative elites to signal the institution of Portugal's own 'third way': not fascism's third way between liberal democracy and Bolshevism, but a hybrid of reactionary conservatism with revolutionary fascism. It was in the aspiration of some architects to demonstrate through additions to the built environment the ethos of innovation and regeneration that

1 Fascism: Journal of Comparative Fascist Studies 7 (2018): 1-108, accessed July 17, 2018, http:// booksandjournals.brillonline.com/content/journals/22116257/7/1. 
corresponded to Portugal's peculiarly 'para-fascist' third way ${ }^{2}$ that Almeida de Carvalho had sensed an affinity between the creation of the totalitarian 'modernist state' - which according to Griffin's analysis, ${ }^{3}$ was the ultimate goal of Fascism and Nazism - and elements of original synthesis visible in the state architecture and urban renewal of Salazar's regime after it had assumed an openly dictatorial form.

The result of the Oxford meeting was the workshop 'Politics and Aesthetics on the Move: The Uses of Architecture in Fascist and Dictatorial Regimes' chaired by Rita Almeida de Carvalho and held at the Institute of Social Sciences at the University of Lisbon (ICS-UL), in May 2014. It brought together Roger Griffin with Aristotle Kallis (History, University of Keele), and Sultana Wahnón (Theory of Literature, University of Granada), for presentations on architectural developments in Hitler's Germany, Mussolini's Italy, Salazar's Portugal, and Franco's Spain respectively, and was attended by professor António Costa Pinto. It was to further explore the thesis that para-fascist regimes reflected in some projects of architectural and urban renewal their underlying kinship with the more radical socio-cultural modernist experiments of the two fascist states, that the participants decided to invite submissions on the interwar architectural scene in Brazil and Argentina. The plan was to devote a special issue of Fascism to architectural modernity in Germany and five 'Latin' societies in the interwar period, one fascist (Mussolini's Italy) and four widely seen, if not as para-fascist, then as influenced by fascism. The articles by Anahi Ballent (University of Quilmes) and Francisco Sales Trajano Filho (University of São Paulo) are the fruit of this decision. Meanwhile, for the sake of coherence, Daniel Domenech (PhD student in the department of the History and Theory of Architecture, University of Granada), whose postgraduate research specializes in the documenting the extraordinary variety of idiosyncratic interwar experimental and modernist buildings in right-wing regimes all over Europe, was invited to write an article focused on architecture under Franco, rather

2 Para-fascism here refers to interwar dictatorial regimes that adopted some of the trappings and policies of the two fascist regimes but without the ultimate totalitarian goal of a total transformation of society, which in the long run would have demanded the destruction of traditional elites, social structures and religious institutions on a par with Bolshevism. See: António Costa Pinto and Aristotle Kallis, ed., Rethinking Fascism and Dictatorship in Europe (London: Palgrave, 2014).

3 This topic is explored in chapters 6, 8, 10 and 11 of Roger Griffin, Modernism and Fascism: The Sense of a Beginning under Mussolini and Hitler (London: Palgrave, 2007). 
than on the Falangist aesthetic theory that had been the subject of the original paper on Spain, a decision approved by Professor Wahnón.

There are several rationales behind the eclectic choice of national case studies, apart from the fact that they cumulatively demonstrate yet again how misguided it was for an earlier generation of scholars to assume that fascisms and their kind were nihilistic, backward-looking, anti-modernity, anti-culture, and operated without a recognizable ideology. One is that for too long comparative fascist studies have remained stubbornly Eurocentric and ignored the wider internationalist dimension of fascism and related authoritarianisms, despite the fact that Plínio Salgado's Ação Integralista Brasileira [AIB; Brazilian Integralist Action] produced a highly original and widely supported, though ultimately abortive, fascist movement, and Peronism in Argentina was clearly influenced by elements of the 'national socialism' pioneered by pre-Axis Italian Fascism. There were other failed movements clearly indebted to European fascism in Chile (Movimiento Nacional Socialista de Chile), South Africa (Ossewabrandwag), India (Indian Legion), China (the Blueshirts), all of which belonged to the extended family of fascist assaults on state power, without forgetting Japan, whose totalitarian regime was not technically fascist (because of its dependency on the traditional cult of a divine emperor), but was deeply indebted for its ethos, organizational structures, and style to events in Nazi Germany in its formative stage. Meanwhile, right-wing regimes in Europe and Latin America displayed varying degrees of 'fascistization' that pointed to an affinity and solidarity with the 'fascist era'.

Second, exploring a topic which brings together fascist with para-fascist dictatorships within the same thematic analysis consciously contributes to the growing scholarly recognition that such movements and regimes must be studied more extensively in their wider historical context and not just as samples of generic fascism and dictatorship. More precisely, they are to be approached as products of a deeply crisis-ridden period of modern history when, as the Spanish Civil War came to symbolize for an entire generation, an almost Manichaean struggle was widely believed to be taking place for the soul of Western civilization. In (partially) Europeanized regimes all over the world two rival strategies for reversing chaos and decline had crystallized in the wake of the Great Depression: various permutations of radical (illiberal) right were pitted against the forces of the radical (illiberal) left. The six articles appearing in this and the last issue of Fascism complement each other in casting a narrow beam of light on a complex, messy world of global socio-political upheaval, crisis and visions of renewal into which the West had descended by the 1930s. It is a beam that illuminates the way architects and town planners 
with anti-liberal, anti-communist, and nationalistic ideals played their part in weaving what David Roberts calls 'the braided dynamic' and 'complex web of interaction' which constituted 'a new universe on the Right' of which fascism was only a 'subset'. ${ }^{4}$ Once this position is accepted, it is no longer possible to treat fascism as a discreet, pure phenomenon which has been abstracted from history, like an organ surgically removed from the living body of history and placed in a jar for investigation. In these six articles the dense connective tissues between separate but organically related cultural phenomena and the political regimes that sponsored or hosted them are intentionally left visible, and the porousness of the membranes between them made evident.

Hopefully, this project will encourage other scholars working in fascist studies to turn their minds to work collaboratively on fruitful case studies in the significant areas of overlap, continuity, and communication that existed between fascisms, conservative revolutions, modernizing para-fascisms, and reactionary conservatisms that arose before 1945 in diverse political, social, and cultural spheres. As more students of fascism adopt this approach, there is bound to be a growing appreciation of the histoires croisées and dynamic transnational borrowings, interactions and influences which characterize the relationship between individual fascisms and other radical right-wing and leftwing policies of the time generated as responses to the deepening structural problems of liberal democracy as a viable form of economic system and political governance, an apparently global crisis which caused so many at every level of society to look for a way out of the cul-de-sac and even postulate the dawning of a 'new era of humanity' ${ }^{5}$

The final rationale, which became particularly evident when the first drafts of all six articles were read together, is that they demonstrate the potential value to comparative studies in fascism, modernity, and cultural innovation of the concept 'rooted modernism'. Certainly, it is a concept that seems to apply to the hybrids between tradition and modern architecture that proliferated under all six regimes. Much time is devoted to making the case for this concept

4 David Roberts, Fascist Interactions: Proposals for a New Approach to Fascism and its Era, 19191945 (New York: Berghahn, 2016), 224-227.

5 This is the main theme of $A$ Quarta Humanidade [The Fourth Humanity] (Rio de Janeiro: Livraria José Olympio, 1934), written by the leader of Brazilian Integralism, Plínio Salgado, but is a recurrent theme too of Italian Fascism (for the centrality of the same palingenetic myth to Italian Fascism, see Pier-Giorgio Zunino, L'ideologia del fascismo: Miti, credenze e valori nella stabilizzazione del regime (Bologna: Il Mulino, 2013), Chapter 2, 'Senso del tempo e senso della storia'. 
in Griffin's article on the architecture of the Third Reich, so space does not need to be devoted to its exposition here, except to suggest that a deep psychological significance and a distinctive cultural statement can be read into the frequent recourse of fascist and para-fascist regimes to stripped classicism or to other, more idiosyncratic attempts to blend allusions to icon building-styles, designs, or techniques from the nation's real or mythic past with ultra-modern elements. They epitomize an age collectively disoriented and traumatized by war, social-economic collapse, the spectre of global civilizational decline, and the threat of Bolshevism, and in need of affective reference points and cultural bearings. While throughout the 'West' elites in every sphere of creativity and reform did their best to point to a path along which their nation could move forwards into what Winston Churchill called 'broad, sunlit uplands', many among them, along with their public, were anxious to keep in sight the reassuring panorama of the lowland valley of the past that stretched beneath, even if its sight was now partially blocked by ominous clouds.

For the purposes of this exploratory exercise in comparative fascist and para-fascist studies, each specialist was invited to write an article within a broadly shared conceptual framework. This accepts the totalitarian and thus revolutionary nature of fascist ultranationalism, which distinguished it from the anti-revolutionary and ultimately anti-fascist nature of para-fascist regimes which partially emulated them, a stance which did not prevent them from borrowing from some of their external features. Given the length of each article it was decided to publish them in two groups of three. In the last issue of Fascism (volume 7, issue 1), Roger Griffin's article on the rooted modernism of Nazi architecture, was followed by Aristotle Kallis' account of the intense competition among highly innovative architects under Mussolini to establish a style which reflected the essential nature of the regime. The third was Anahi Ballent's survey of the varied architectural aesthetics that came into being under Peronism, a political ideology and system partly inspired by Italian Fascism, even though the Axis Powers had already been defeated. The aspirations, aesthetics, and building projects considered in her article resonate strikingly with those of the two fascist regimes examined in the earlier articles. What emerges too is the sheer variety of the permutations of a modernism rooted in the values of an often mythicized past, which form a hidden common denominator of attempted schemes of cultural renewal under Hitler, Mussolini, and Perón despite their obvious contrasts.

In the present issue, the architecture of three clearly para-fascist regimes comes under the spotlight: those of Spain, Portugal, and Brazil, in each of which a genuine fascist movement was either absorbed into a right-wing dictatorship 
(as occurred under Franco) or disbanded by it while perceptibly retaining some fascist elements (as in the case of the Salazar and Vargas regimes). Once again, the juxtaposition of the articles reveals unexpected elements of internationalism, entanglements, and histoires croisées both sides of the Atlantic in the impact of the fascist experiments in Germany and Italy. It would be heartening to think that the combined impact of this two-part special issue will be to encourage historians of such disparate fields as Art, Culture, Literature, Anthropology, socio-political theory, eugenics, cinema, town planning, Law, political religion and state propaganda, to be lured into the comparative studies of developments under fascist, para-fascist, or conservative right-wing regimes in the twentieth century which bear witness to the fact that the conquest of power and creation of a new type of state by fascist movements in Italy and Germany did indeed give rise for over a decade of modern history a 'fascist era'.

This term is certainly not to be understood as referring to the spontaneous overthrow of liberal or conservative regimes by fully-fledged fascist states all over the world. Far from it. But it suggests that the two fascist regimes offered role models for how to bring about national greatness, a dynamic future, and national renewal secured through the, sometimes ruthless, deployment of a monopoly power of state power, thereby generating a gravitational force within nationalist politics which curved political, social, and cultural space towards them. The age of individualism, laissez-faire capitalism and the 'nightwatchman' state seemed over for good. A bulwark had to be created by the modern state against the societal breakdown being presided over by liberalism and the destruction of tradition, religion, and the nation threatened by the spread of Bolshevism. The solution was a state based on powerful nationalism, with or without a radically anti-conservative, revolutionary agenda of transformation. The high degree of improvisation demanded by movements and state agencies in the chaotic, crisis-ridden national and international situation of the interwar period is reflected in the plural, profoundly incoherent schemes for architectural renewal. Yet even in their heterogeneity and frequent derivativeness, the projects reviewed in these six articles also reflect how architects, the most optimistic of creative artists, struggled to establish visual and mental templates which would point the way to alternative modernities, new worlds and undreamt utopias.

They have been written in the hope that the experimental, futural, and sometimes even ludic quality of some architecture and town planning in the fascist era will gain wider recognition as aspects of an attempted cultural renaissance. Peter Adam exhorted us in Art of the Third Reich to see everything 
the Nazis produced in the name of culture 'through the lens of Auschwitz' and hence 'as the artistic expression of a barbaric ideology'. ${ }^{6}$ By contrast, these essays invite readers not to misinterpret fascist and para-fascist experimentation and innovation in the cultural sphere by their inevitable association with state terror, total war and genocide. Rather they are to be approached as a largely spontaneous and often creative response to the depths of the interwar crisis, and as the expression of often impressively imaginative quests for new civilizational meanings, tasks, and forms symbolizing hope in a new future, and a new modernism.

6 Peter Adam, Art of the Third Reich (New York: Abrams, 1992), 9. 